\title{
Coastal bermudagrass and Renner lovegrass fertilization responses in a subtropical climate
}

\author{
ROBERT P. WIEDENFELD
}

\section{Abutract}

Forage production in subtropical regions usually requires fertilization to meet plant nutrient needs. This study was conducted to determine the influence of $\mathrm{N}$ and $\mathrm{P}$ application on yield response, nutrlent uptake, and apparent fertilizer and water use effeiency of 2 grasses on a subtropical cosstal prairle. Treatments conaisting of factoral combinations of 0,112 , and $224 \mathrm{ks} N /$ ha and 0,15 , and 29 $\mathrm{kE} P /$ ha were annually applled to coastal bermudagrass (Cynodon dactylon (L.) Pern.) and Renner lovegrass (Eragrostis curvula (Schard.) Neas) on Sartia fine and (eromarenic paleustaln in South Texas. Cuttings were made 2 to 4 times per year for 4 years. Soll samples taken annually and plant samples from each cutting were analyzed for $\mathbf{N}$ and $\mathbf{P}$ concentration. Forage ylelds by both erasues improved dramatically with $\mathbf{N}$ application, but to a much leaser degree with $\mathbf{P}$ application. While yields were also strongly dependent on rainfall level, $\mathbf{N}$ subatantially improved forage yield per unit of rainfall recelved. Forage concentration of both $N$ and $P$ increased with inereasing application rates of each nutrient. Apparent fertilizer recovery fluctuated between years, reflecting atand age and rainfall; however, fertillzer rate had no effect. None of the fertilizer $\mathbf{N}$ not removed in the forage could be found as inorganic $\mathbf{N}$ at the 0 to $.3-\mathrm{m}$ soll depth, while up to $20 \%$ of the $\mathrm{P}$ applied remained available in the soll. Between 65 and $80 \%$ of the fertilizer applied was not ued by the forage grasses. Improvements in forage yield and quality with $\mathbf{N}$ and $\mathbf{P}$ fertilization juatify their use, even though ineficiency of fertilizer recovery and we ts subatantial.

Key Words: Cynodon dactylon, Eragrostis curvula, nitrogen, phoophorus, yield, apparent fertilizer recovery, rainiall we eficiency

Forage production from native rangeland and improved pastures is a major land use in dry, subtropical regions. Forage grasses constitute the primary crops on most of the mixed-brush rangeland in the southern Texas and northern Mexico resource area known as the Rio Grande Plain. Coastal bermudagrass (Cynodon dactylon (L.) Pers.) and 'Renner' weeping lovegrass (Eragrostis curvula (Schrad.) Nees) are subtropical grasses well adapted to sandy sites. Coastal bermudagrass is grown extensively throughout the southeastern United States. It is a stoloniferous, warm-season perennial with good yield and moderate forage quality. Renner lovegrass is a stiff perennial bunchgrass introduced from Africa. It is planted extensively in the southern United States for conservation and forage. Lovegrass palatability to grazing animals is lower than that of many cultivated grasses, frequently giving low rates of gain (Holt and Dalrymple 1979).

Subtropical conditions increase nutrient requirements by accelerating nutrient cycling in the ecosystem (Russel et al. 1974), and subtropical soils are typically infertile. Forage yields on sandy soils have shown good responses to applied $\mathrm{N}$ in Florida (Blue 1971, Wallace et al. 1955) and in southern Texas (Mutz and Drawe 1983, Wiedenfeld et al. 1985). Forage yield responses to $P$ fertilization have occurred primarily as $\mathbf{N}$ becomes nonlimiting (Lorenz and

\footnotetext{
Author is associate professor, Texas AdM Univ. Agr. Res. and Ext. Center, Wealaco, Texas 78596.

This study is a contribution of the Texas Agr. Exp. Sta., Texas A\&M Univ., College Station, TX 77843 and was partially supported by Metz \& Kappler, Edinburg (now Rio-Ag Products); American Agri-Services, Elsa (now Rio Ag Products); and Tide Products, Edinburg.

Manuscript accepted 13 August 1987.
}

Rogler 1972, Wight 1976, Wight and Black 1979). Fertilization has been shown to increase soil water extraction by forages (Fairbourn 1982, Thomas and Osenbrug 1964, Wight and Black 1978) and to improve rainfall use efficiency (Wiedenfeld et al. 1985, Wight and Black 1979). Forage nutrient content in subtropical regions is typically low (Holt and Dalrymple 1979, Gonzalez and Everett 1982) but increases with fertilization (Prine and Burton 1956, Wiedenfeld et al. 1985). Nutrient uptake by forages in drier subtropical environments has been shown to be affected by species (Impithuksa and Blue 1985) as well as by application rate and rainfall.

This study was conducted to determine the influence of $\mathrm{N}$ and $\mathrm{P}$ fertilization on yield response, nutrient uptake, and apparent fertilizer and water use efficiency of 2 grasses established on a dry, subtropical coastal prairie.

\section{Materials and Methods}

A field study was initiated in the spring of 1980 in northern Willacy County of Texas on a Sarita fine sand (loamy, mixed, hyperthermic Grossarenic Paleustalfs); a deep, gently undulating, well-drained soil with an average $\mathrm{pH}$ of 6.7 and less than $1 \%$ organic matter content. The area is semi-arid, averaging $68.6 \mathrm{~cm}$ of rainfall annually with peaks in May and August, and subtropical with an average growing season of 331 days. The study area was prepared by disking several times to remove native grass competition and to provide a good seed bed. Coastal bermudagrass sprigs were hand planted in one 0.2 -ha area on 0.5 -m centers. Renner lovegrass seed was broadcast on another 0.2 -ha area at a rate of $2.24 \mathrm{~kg} / \mathrm{ha}$ and incorporated by rolling.

Plots 3.1 by $10.2 \mathrm{~m}$ were established on each area for annual fertilizer treatments consisting of 0,112 , and $224 \mathrm{~kg} \mathrm{~N} / \mathrm{ha}$ and 0,15 and $29 \mathrm{~kg} \mathrm{P} /$ ha combined in a factorial arrangements. The 9 treatments were replicated 4 times in a randomized complete block design for each grass. All fertilizers were applied broadcast, with $P$ applied as a single application in the spring of each year as concentrated super phosphate $(0-44-0)$, and $\mathrm{N}$ applied annually as ammonium nitrate (33-0-0) in 3 split applications (once in the spring and after each of the first 2 harvests). Rainfall received annually is shown in Table 1 . Adequate rainfall was received in May $1980(12.0 \mathrm{~cm})$ to insure establishment of the coastal bermudagrass and germination of the lovegrass; however, during June and July only $2.3 \mathrm{~cm}$ of rainfall was received and neither grass grew adequately to permit a harvest. All of the $P$, but only one third of the $\mathrm{N}$ prescribed by the treatment plan were applied in 1980 . In

Table 1. Annual rainfall received at the atudy site in northern Willacy County of Texas.

\begin{tabular}{ll}
\hline \hline Year & Rainfall \\
\hline & $-\mathrm{cm}-$ \\
1980 & 63.8 \\
1981 & 97.9 \\
1982 & 54.3 \\
1983 & 71.6 \\
1984 & 66.0 \\
\hline
\end{tabular}


1982, the third application of $\mathrm{N}$ was made in September even though there was no second harvest.

Prior to the fertilizer applications, soil samples were taken in the spring of each year from 1980 through 1985. In 1980, soil samples were taken from random spots throughout the area in depth increments of $0-0.3,0.3-0.6$, and $0.6-0.9 \mathrm{~m}$. Soil $\mathrm{NO}_{3}-\mathrm{-N}$ was determined by using a salicylic-sulfuric acid colorimetric procedure on a $\mathrm{CaCl}_{2}$ extract. Soil $\mathbf{P}$ was determined by extracting with $\mathrm{NH}_{4} \mathrm{Ac}-\mathrm{HCl}$-EDTA at $\mathrm{pH} 4.2$ then using the molybdenum blue colorimetric method (Jackson 1970). In subsequent years, one soil sample was taken from each plot to a depth of $0.3 \mathrm{~m}$. These samples were analyzed for $\mathrm{NH}_{4}{ }^{+}$-and $\mathrm{NO}_{3}-\mathrm{N}$ content using $\mathrm{KCl}$ extraction and Kjeldahl distillation (Bremner 1965). Available soil $P$ wás extracted with $\mathrm{NH}_{4} \mathrm{Ac}-\mathrm{HCl}$ at $\mathrm{pH} 4.2$ and then the molybdenum blue colorimetric method.

Yields were determined by harvesting all plots 1 to 3 times each year. A strip 1.0 by $8.2 \mathrm{~m}$ was cut from each plot using a flail-type harvester and samples were weighed to determine fresh weight. All remaining forage was removed with the harvester from each plot. Subsamples were dried at $60^{\circ} \mathrm{C}$ for $48 \mathrm{hr}$ to convert fresh weights to a dry weight basis. The forage subsamples were then ground and analyzed for $\mathbf{N}$ and $\mathbf{P}$ content. Nitrogen was determined by a sulfuric-salicylic acid digestion and $\mathrm{Kjeldahl} \mathrm{distillation;} \mathrm{and} \mathbf{P}$ was determined by a dry ashing then a vanadomolybdophosphoric yellow colorimetric method in a sulfuric acid system (Jackson 1970).

Yields and tissue nutrient concentrations were used to calculate total $\mathbf{N}$ and $\mathbf{P}$ removal in each harvest; then $\mathbf{N}, \mathrm{P}$, and dry matter yields were accumulated on an annual basis. Apparent fertilizer recovery was calculated as the amount of each nutrient in the forage harvested minus the amount removed from the check plot for that block where no fertilizer was applied, divided by the amount of nutrient applied in the fertilizer (Wiedenfeld et al. 1985).

Data were analyzed statistically using response surface-type multiple linear regression models which included linear and quadratic elements for treatment main effects and also a linear crossproduct term. Where model parameter estimates are given, factors were chosen for inclusion in the model based on stepwise selection procedures. All analyses were done using the SAS system for data analysis (SAS Institute Inc. 1985).

\section{Results and Discussion}

Soil analyses prior to the first fertilizer applications showed $\mathrm{NO}_{3}{ }^{-}-\mathrm{N}$ levels averaged $9 \mathrm{ppm}$, and $\mathrm{P}$ levels were low to very low' in the surface $0.3 \mathrm{~m}$. Soil levels of both plant nutrients decreased with depth. Other plant nutrients were at levels (data not included) considered not limiting for plant growth.

Increasing $\mathbf{N}$ application caused significant linear increases in total soil inorganic $\mathrm{N}\left(\mathrm{NH}_{4}{ }^{+}-\mathrm{N}+\mathrm{NO}_{3}{ }^{-}-\mathrm{N}\right)$ for Renner lovegrass in 1982 and 1983, but only in 1985 for coastal bermudagrass (Fig. 1). Increases in inorganic soil $\mathbf{N}$ with $\mathbf{N}$ applied, and increased overall soil $\mathrm{N}$ levels were more likely following drier years and for the grass having lower $\mathrm{N}$ uptake. Such patterns were small in magnitude and duration, indicating no long-term trend in inorganic soil $\mathbf{N}$.

Soil $\mathbf{P}$ levels showed a significant linear relationship with $\mathbf{P}$ application rate for both grasses each year (Fig. 2). Furthermore, trends over the four-year period indicated that soil $P$ was being depleted where No $\mathbf{P}$ was being applied, but remained constant where $15 \mathrm{~kg} P$ ha/yr was being applied and accumulated when 29 $\mathrm{kg} \mathrm{P} / \mathrm{ha} / \mathrm{yr}$ was being applied. Nitrogen application affected soil $\mathrm{P}$ levels on both grasses in 1985, and $N$ and $P$ application had an interactive effect on soil P levels in 1982 on Renner lovegrass and in 1983 on coastal bermudagrass (data not shown), each case indicating a decrease in soil $\mathbf{P}$ as $\mathbf{N}$ increased.

Forage yields in this study were affected by fertilizer application, rainfall received, and also by the chronological age of the grasses.

Response surface regression analyses showed forage yield responses to fertilizer application by both grasses over all years studied (Figs. 3 and 4). A positive parameter estimate for $\mathbf{N}^{2}$ in the equations for coastal bermudagrass 3 out of 4 years indicated increasing yield response per unit of $\mathrm{N}$ with increasing $\mathrm{N}$ rates. In the $\mathbf{2}$ years that the parameter for $\mathrm{N}^{2}$ was significant for Renner lovegrass yield, the value was negative and indicated a decreasing marginal benefit from $\mathbf{N}$ application. Yield responses indicated that coastal bermudagrass could have made efficient use of $\mathrm{N}$ rates above those established in this study, while lovegrass yield patterns suggest a less efficient use of $\mathrm{N}$ rates greater than those applied. A

ITexas Extension Soil Testing Laboratory $P$ ratings are: very low 0-5, low 6-10, medium 11-20, high $21-40$, and very high $>40 \mathrm{ppm}$.

\section{Soil N Levels}
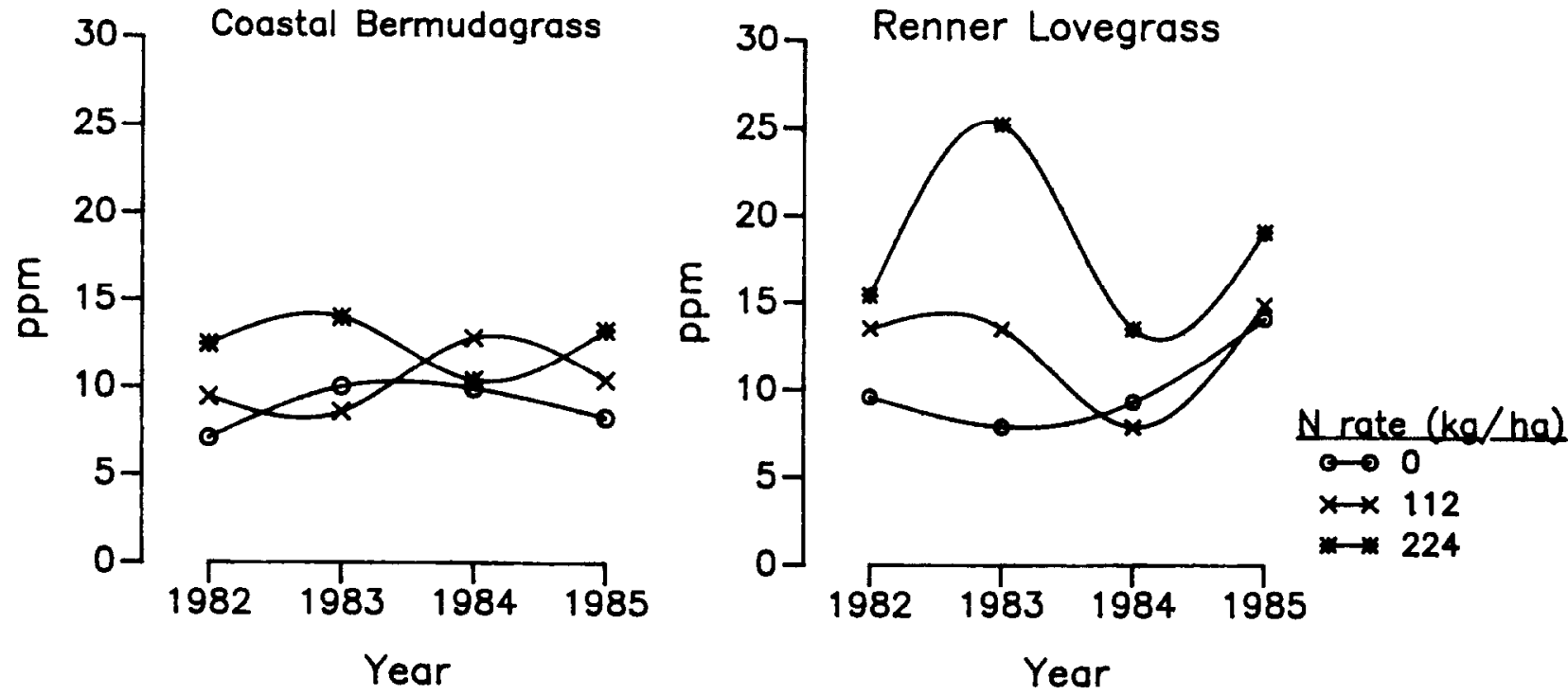

Fis. 1. Residual soil inorganic $N\left(H_{4}^{+}-N+N O_{3}-N\right)$ at $0-0.3 m$ depth for 3 rates of $N$ fertilizer application in previous years on 2 grasses. 
Table 2. Fertilization effects on nutrient concentration of the forage grasses at the difierent harvest dates.

\begin{tabular}{|c|c|c|c|c|c|c|c|c|c|c|}
\hline \multirow[b]{2}{*}{ Treatments } & \multirow[b]{2}{*}{ Grass } & \multicolumn{3}{|c|}{1981} & \multirow{2}{*}{$\frac{1982}{06 / 10}$} & \multicolumn{3}{|c|}{1983} & \multicolumn{2}{|c|}{1984} \\
\hline & & $06 / 23$ & $10 / 06$ & $12 / 18$ & & $06 / 29$ & $09 / 15$ & $12 / 08$ & $06 / 10$ & $12 / 10$ \\
\hline \multirow[b]{2}{*}{$\begin{array}{l}\text { N rate }(\mathrm{kg} / \mathrm{ha}) \\
0 \\
112 \\
224 \\
\text { Significancel }\end{array}$} & & & & & $-\mathbf{N}$ & entratio & (\%)- & & & \\
\hline & $\begin{array}{l}\text { Coastal } \\
\text { bermudagrass }\end{array}$ & $\begin{array}{l}1.94 \\
1.80 \\
1.43 \\
\mathrm{~ns}\end{array}$ & $\begin{array}{l}0.66 \\
0.63 \\
0.73 \\
\text { ns }\end{array}$ & $\begin{array}{l}1.06 \\
1.37 \\
1.46 \\
L^{* * *}\end{array}$ & $\begin{array}{l}0.82 \\
0.77 \\
0.82 \\
\text { ns }\end{array}$ & $\begin{array}{l}1.08 \\
1.22 \\
1.50 \\
L^{* * *}\end{array}$ & $\begin{array}{l}0.82 \\
0.84 \\
1.12 \\
Q^{* *}\end{array}$ & $\begin{array}{l}0.86 \\
1.01 \\
1.19 \\
L^{* * *}\end{array}$ & $\begin{array}{l}1.15 \\
1.55 \\
1.64 \\
Q^{* *}\end{array}$ & $\begin{array}{l}0.89 \\
1.17 \\
1.38 \\
L^{* * *}\end{array}$ \\
\hline $\begin{array}{c}0 \\
112 \\
224 \\
\text { Significance }\end{array}$ & $\begin{array}{l}\text { Renner } \\
\text { Lovegrass }\end{array}$ & $\begin{array}{l}1.67 \\
1.69 \\
1.45 \\
\text { ns }\end{array}$ & $\begin{array}{l}0.78 \\
0.77 \\
0.85 \\
-\end{array}$ & $\begin{array}{l}1.09 \\
1.27 \\
1.54 \\
L * *\end{array}$ & $\begin{array}{l}0.65 \\
0.72 \\
0.84 \\
L^{* * *}\end{array}$ & $\begin{array}{l}0.80 \\
0.98 \\
1.10 \\
L^{* * *}\end{array}$ & $\begin{array}{l}0.79 \\
0.97 \\
1.18 \\
L^{* * *}\end{array}$ & $\begin{array}{l}0.87 \\
1.03 \\
1.14 \\
L^{* * *}\end{array}$ & $\begin{array}{l}0.98 \\
1.19 \\
1.36 \\
L * *\end{array}$ & $\begin{array}{l}0.90 \\
1.18 \\
1.36 \\
L^{* * *}\end{array}$ \\
\hline \multirow{2}{*}{\multicolumn{2}{|c|}{$\begin{array}{cl}\text { P rate }(\mathrm{kg} / \mathrm{ha}) & \\
0 & \text { Coastal } \\
15 & \text { bermudagrass } \\
29 & \\
\text { Significance } & \end{array}$}} & & & & $-\mathbf{P}$ & entratio & $(\%)$ & & & \\
\hline & & $\begin{array}{l}0.08 \\
0.11 \\
0.12 \\
L^{* *}\end{array}$ & $\begin{array}{l}0.08 \\
0.11 \\
0.14 \\
L^{* * *}\end{array}$ & $\begin{array}{l}0.09 \\
0.12 \\
0.14 \\
L^{* * *}\end{array}$ & $\begin{array}{l}0.07 \\
0.13 \\
0.16 \\
L^{* * *}\end{array}$ & $\begin{array}{l}0.08 \\
0.15 \\
0.18 \\
Q^{* *}\end{array}$ & $\begin{array}{l}0.09 \\
0.16 \\
0.20 \\
L\end{array}$ & $\begin{array}{l}0.10 \\
0.14 \\
0.18 \\
L^{* * * *}\end{array}$ & $\begin{array}{l}0.10 \\
0.16 \\
0.19 \\
-\end{array}$ & $\begin{array}{l}0.07 \\
0.11 \\
0.13 \\
-\end{array}$ \\
\hline $\begin{array}{c}0 \\
15 \\
29 \\
\text { Significance }\end{array}$ & $\begin{array}{l}\text { Renner } \\
\text { Lovegrass }\end{array}$ & $\begin{array}{l}0.08 \\
0.11 \\
0.18 \\
L^{* * *}\end{array}$ & $\begin{array}{l}0.08 \\
0.12 \\
0.15 \\
L^{* * *}\end{array}$ & $\begin{array}{l}0.09 \\
0.11 \\
0.15 \\
L^{* * *}\end{array}$ & $\begin{array}{l}0.07 \\
0.10 \\
0.12 \\
L^{* * *}\end{array}$ & $\begin{array}{l}0.06 \\
0.09 \\
0.10 \\
Q^{*}\end{array}$ & $\begin{array}{l}0.09 \\
0.14 \\
0.16 \\
L^{* * *}\end{array}$ & $\begin{array}{l}0.09 \\
0.11 \\
0.14 \\
L^{* * *}\end{array}$ & $\begin{array}{l}0.07 \\
0.11 \\
0.13 \\
L * *\end{array}$ & $\begin{array}{l}0.07 \\
0.10 \\
0.13 \\
L^{* * *}\end{array}$ \\
\hline
\end{tabular}

'Differences between means were non-significant (ns) or showed linear $(\mathrm{L})$ or quadratic $(\mathrm{Q})$ responses at the $5 \%\left({ }^{*}\right), 1 \%\left(^{* *}\right)$ or $0.1 \%\left(^{* * *}\right)$ level. Where significance is not shown, interactions occurred.

Table 3. Fertilization effects on total annual nutrient removal by 2 grasses over 4 years.

\begin{tabular}{|c|c|c|c|c|c|c|c|c|}
\hline \multirow[b]{2}{*}{ Treatments } & \multicolumn{4}{|c|}{ Coastal bermudagrass } & \multicolumn{4}{|c|}{ Renner Lovegrass } \\
\hline & 1981 & 1982 & 1983 & 1984 & 1981 & 1982 & 1983 & 1984 \\
\hline $\begin{array}{c}\text { N rate }(\mathbf{k g} / \mathrm{ha}) \\
0 \\
112 \\
224 \\
\text { Significancel }\end{array}$ & $\begin{array}{l}54.0 \\
59.7 \\
85.1 \\
L^{* * *}\end{array}$ & $\begin{array}{r}9.2 \\
18.9 \\
37.5 \\
Q^{*}\end{array}$ & $\begin{array}{r}43.2 \\
87.8 \\
143.7 \\
L^{* * * *}\end{array}$ & $\begin{array}{l}32.9 \\
55.5 \\
84.6 \\
L^{* * * *}\end{array}$ & $\begin{array}{l}1 \mathrm{~kg} / \mathrm{ha}) \\
34.2 \\
45.8 \\
55.1 \\
\mathrm{~L}^{* * * *}\end{array}$ & $\begin{array}{l}11.2 \\
31.2 \\
47.1 \\
L^{* * * *}\end{array}$ & $\begin{array}{r}63.4 \\
115.9 \\
121.7 \\
Q^{* * *}\end{array}$ & $\begin{array}{l}32.7 \\
52.7 \\
63.1 \\
L * * *\end{array}$ \\
\hline $\begin{array}{c}\text { P rate (kg/ha) } \\
0 \\
15 \\
29 \\
\text { Significance }\end{array}$ & $\begin{array}{l}4.21 \\
6.86 \\
9.14 \\
L^{* 4 *}\end{array}$ & $\begin{array}{c}1.54 \\
3.24 \\
4.77 \\
-\end{array}$ & $\begin{array}{r}7.98 \\
12.80 \\
16.74 \\
L^{* * *}\end{array}$ & $\begin{array}{l}3.91 \\
5.19 \\
6.25 \\
L^{* * *}\end{array}$ & $\begin{array}{c}(\mathrm{kg} / \mathrm{ha}) \\
2.97 \\
5.07 \\
7.50 \\
\mathrm{~L}^{* * *}\end{array}$ & $\begin{array}{l}2.55 \\
4.02 \\
5.21 \\
L^{*} *\end{array}$ & $\begin{array}{r}7.16 \\
12.09 \\
14.18 \\
Q^{*}=\end{array}$ & $\begin{array}{l}3.04 \\
4.57 \\
5.03 \\
L^{* * *}\end{array}$ \\
\hline $\begin{array}{c}\text { N rate }(\mathrm{kg} / \mathrm{ha}) \\
0 \\
112 \\
224 \\
\text { Significance }\end{array}$ & $\begin{array}{r}5.64 \\
6.24 \\
8.33 \\
I\end{array}$ & $\begin{array}{c}1.45 \\
3.03 \\
5.08 \\
-\end{array}$ & $\begin{array}{r}7.86 \\
13.09 \\
16.57 \\
L^{* * *}\end{array}$ & $\begin{array}{l}4.13 \\
4.48 \\
6.73 \\
L\end{array}$ & $\begin{array}{c}4.24 \\
5.60 \\
5.71 \\
\text { ns }\end{array}$ & $\begin{array}{c}1.64 \\
4.41 \\
5.73 \\
L^{* * *}\end{array}$ & $\begin{array}{c}8.65 \\
13.23 \\
11.55 \\
Q^{*}\end{array}$ & $\begin{array}{l}3.42 \\
4.42 \\
4.80 \\
L * * *\end{array}$ \\
\hline
\end{tabular}

Differences between means were nonsigificant (ns), or showed linear $(\mathrm{L})$ or quadratic $(Q)$ responses at the $5 \%(*), 1 \%(* *)$ or $0.1 \%\left({ }^{* * *}\right)$ level. Where significance is not shown, interactions occurred.

Table 4. Effects of $\mathbf{N}$ application on apparent $\mathbf{N}$ and $\mathbf{P}$ fertilizer use efinciency.

\begin{tabular}{|c|c|c|c|c|c|c|c|c|}
\hline \multirow[b]{2}{*}{ Treatments } & \multicolumn{4}{|c|}{ Coastal bermudagrass } & \multicolumn{4}{|c|}{ Renner Lovegrass } \\
\hline & 1981 & 1982 & 1983 & 1984 & 1981 & 1982 & 1983 & 1984 \\
\hline \multirow{2}{*}{$\begin{array}{l}\text { N rate (kg/ha) } \\
112 \\
224\end{array}$} & \multicolumn{8}{|c|}{$\mathrm{N}$ fertilizer use efficiency $(\%)$} \\
\hline & $\begin{array}{r}5.2 \\
13.9\end{array}$ & $\begin{array}{r}8.6 \\
12.6\end{array}$ & $\begin{array}{l}39.8 \\
44.9\end{array}$ & $\begin{array}{l}17.5 \\
23.1\end{array}$ & $\begin{array}{r}10.4 \\
9.4\end{array}$ & $\begin{array}{l}17.8 \\
16.0\end{array}$ & $\begin{array}{l}46.9 \\
26.1\end{array}$ & $\begin{array}{l}17.8 \\
13.6\end{array}$ \\
\hline Significancel & ns & $*$ & ns & ns & ns & ns & $*$ & ns \\
\hline \multirow{2}{*}{$\begin{array}{c}\text { N rate }(\mathbf{k g} / \mathbf{h a}) \\
0 \\
112 \\
224\end{array}$} & \multicolumn{8}{|c|}{-P fertilizer use efficiency $(\%)$} \\
\hline & $\begin{array}{l}13.1 \\
16.6 \\
22.4\end{array}$ & $\begin{array}{r}5.2 \\
10.3 \\
18.3\end{array}$ & $\begin{array}{l}28.8 \\
30.1 \\
33.8\end{array}$ & $\begin{array}{l}8.7 \\
6.3 \\
9.9\end{array}$ & $\begin{array}{l}10.2 \\
15.9 \\
18.3\end{array}$ & $\begin{array}{r}1.1 \\
15.4 \\
11.9\end{array}$ & $\begin{array}{l}22.5 \\
35.0 \\
28.1\end{array}$ & $\begin{array}{l}6.7 \\
9.7 \\
9.3\end{array}$ \\
\hline Significance & ns & $\mathrm{L}^{* * *}$ & ns & ns & ns & $Q^{*}$ & ns & ns \\
\hline
\end{tabular}

'Differences between means were nonsignificant (ns), or significant at the $5 \%\left({ }^{*}\right), 1 \%(* *)$ or $0.1 \%(* * *)$ level. For P fertilizer use efficiency, significant responses were linear (L) or quadratic (Q). 


\section{Soil P Levels}
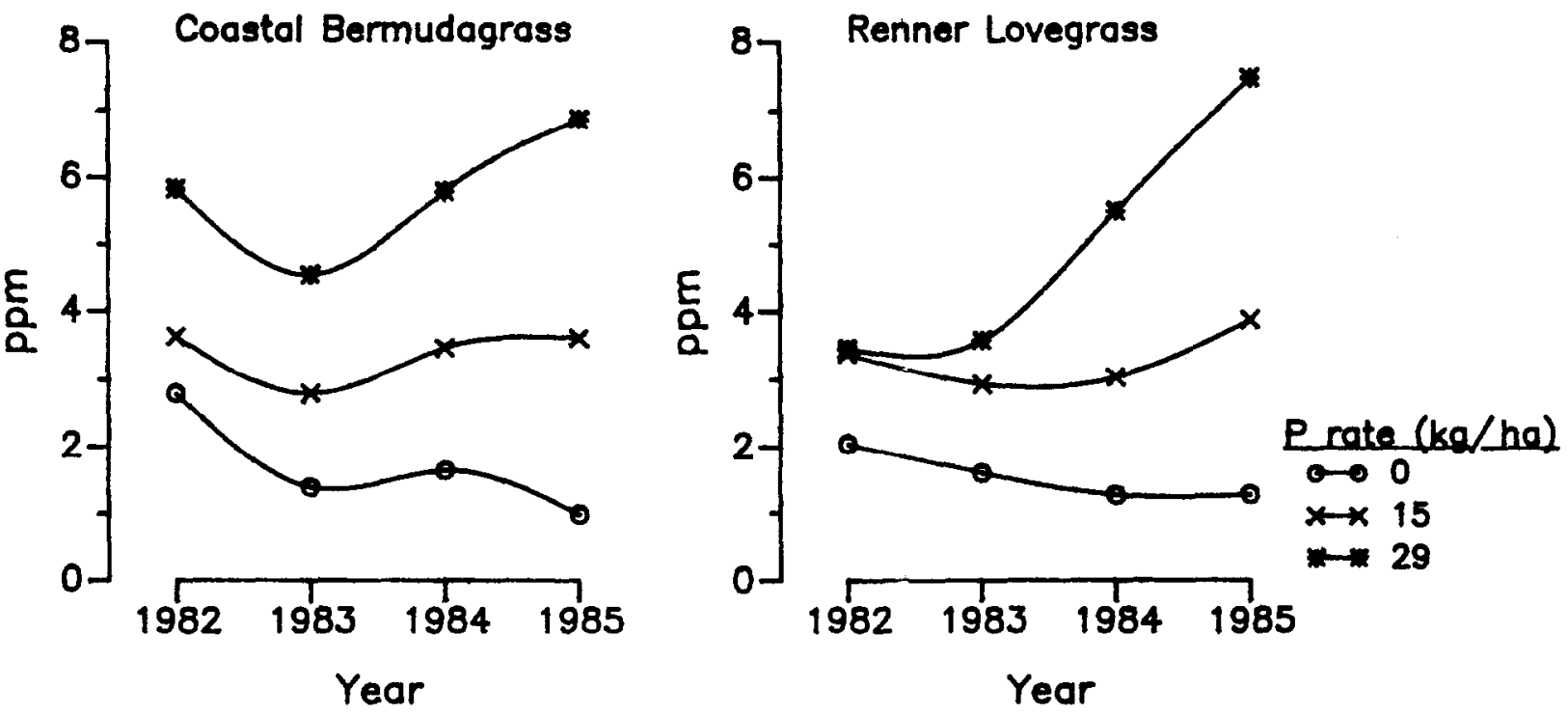

Fis. 2. Residual soil available $P$ at $0-0.3 \mathrm{~m}$ depth for 3 rates of $P$ fertilizer application in previous years on 2 grasses.

significantly yield response to $P$ application occurred independently or interactively with $\mathbf{N}$ rate in some years for both grasses.

While nutrient availability, principally $\mathrm{N}$, was clearly a limiting factor on yields, rainfall also strongly influenced production. The greatest rainfall was received in 1981 but stands of both grasses were not yet established adequately to produce maximum yields. More rain was received in 1983 than either 1982 or 1984 , and increased overall yields reflected this benefit. Water received is an uncontrolled resource which cannot be changed; however, apparent rainfall use efficiency, represented as yield per unit of rainfall, was increased dramatically in most cases with increasing $\mathbf{N}$ application (Fig. 5). When $\mathrm{N}$ has been reduced as a limiting factor in this and other studies (Thomas and Osenbrug 1964, Wiedenfeld et al. 1985), yield per unit of rainfall received has often more than doubled.

Concentrations of both $\mathbf{N}$ and $\mathbf{P}$ in forage grasses generally increased with increasing application rates of each nutrient (Table 2). Nutrient concentrations also varied substantially between harvests, probably reflecting differences in growing conditions. Highest nutrient concentrations occurred at those harvests producing the greatest yields, indicating that $\mathbf{N}$ taken up was not diluted at high yield levels; however, $P$ concentrations did suffer a reduction as yields increased with increasing $\mathbf{N}$ rate. Nitrogen concentrations, particularty when enhanced by $\mathbf{N}$ application, indicated a good quality forage. Recommendations for $\mathbf{P}$ levels in cattle diets range from .18 to $.22 \%$ depending on the reference and the class of livestock. Forage $P$ concentrations in this study, however, rarely reached this range.

Total annual $\mathrm{N}$ removal by both grasses was increased substantially with $\mathrm{N}$ application, reflecting both the yield response and the increase in $\mathbf{N}$ concentration with increasing $\mathrm{N}$ rate (Table 3 ). Total $P$ removal represented both increasing forage $P$ concentration with increasing $\mathbf{P}$ applied, and increasing yield with increasing $\mathbf{N}$ applied (Table 3).

Apparent fertilizer recovery fluctuated greatly from year to year, again reflecting both the age of the stand and rainfall received (Table 4). When higher rainfall resulted in better yields, the best $N$ fertilizer recoveries of approximately $45 \%$ and the best $P$ fertilizer recoveries of about $35 \%$ were obtained. Average $\mathrm{N}$ and $\mathrm{P}$ fertilizer recoveries for both grasses at all application levels over the 4-year period were 20 and $16 \%$, respectively. In only a few situations did increasing rate of $\mathbf{N}$ application have an effect on apparent $N$ and $P$ fertilizer use efficiency. Fertilizer recovery by forages in more temperate climates is typically somewhat better (Thomas and Osenbrug 1964). However, compared to annual row crops grown

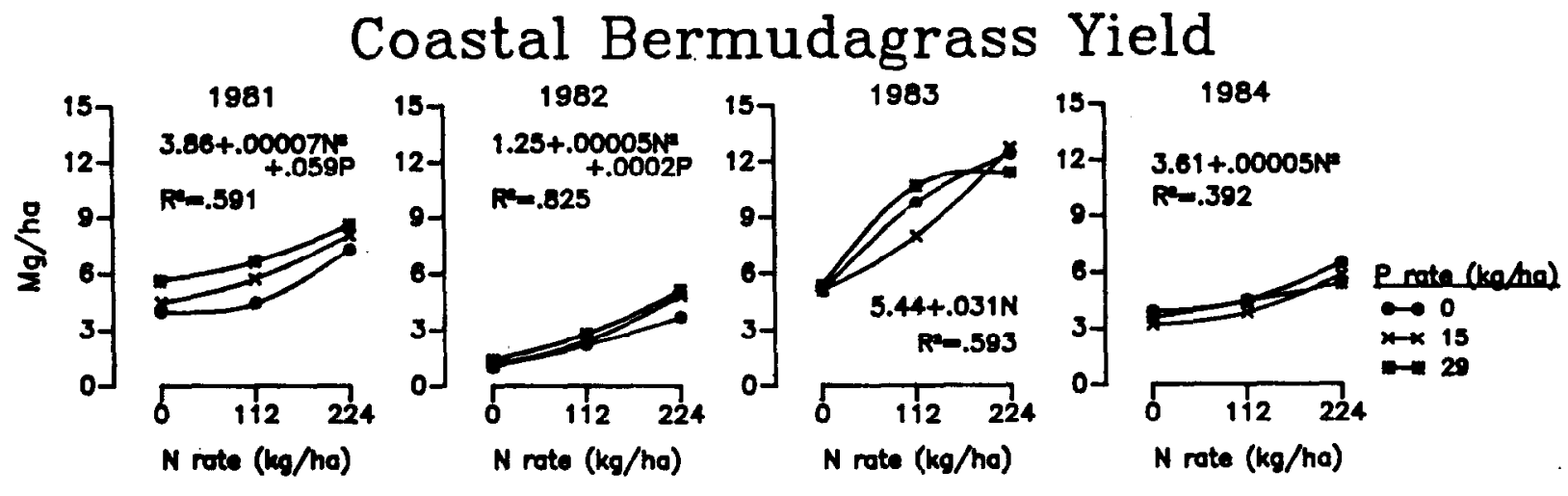

Fig. 3. Dry matter yields of coastal bermudagrass at the different levels of $N$ and $P$ application. The equation for the response surface model containing the significant parameters, and the associated $R^{2}$ values are shown for each year. 


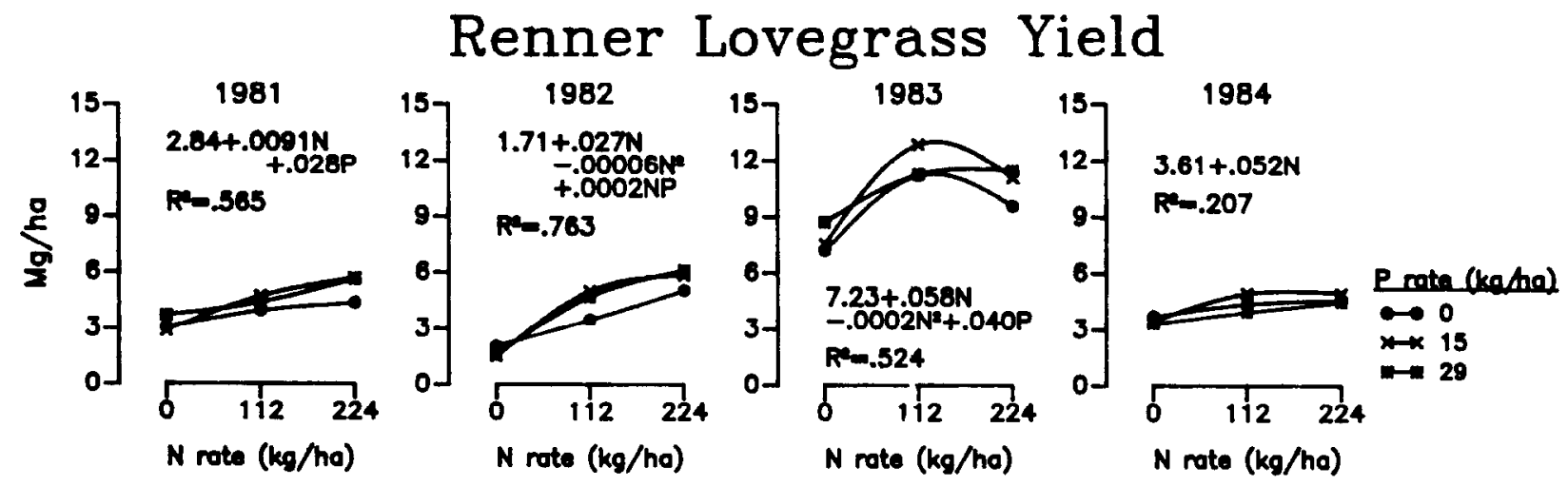

Fic. 4. Dry matter yields of Renner lovegrass at the different levels of $N$ and $P$ application. The equation for the response surface model containing the significant parameters and the associated $R^{2}$ values are shown for each year.

in this same environment although on different soil types, $\mathbf{N}$ fertilizer recovery is roughly the same and $P$ fertilizer recovery by these forage grasses is better.

The annual soil test for inorganic soil $\mathrm{N}$ failed to locate much of the unutilized fertilizer $\mathbf{N}$ which suggested that it had been volatilized shortly after application, bound in the organic fractions of the soil, or lost due to leaching. For phosphorus, $16 \%$ of the amount applied was accounted for in the forage harvested and an additional 17 to $20 \%$ was accounted for as the increased available soil $P$ in the top $30 \mathrm{~cm}$ as determined by the annual soil tests. The remainder of the $P$ applied was probably bound in the organic component or as insoluble $P$ compounds.

Fertilization with both $\mathbf{N}$ and $\mathbf{P}$ was beneficial to both grasses studied in terms of yield and quality. The yield responses to $P$ application were small; however, at low $P$ levels, some forage species will not persist. Nitrogen application produced a substantial yield benefit, providing strong justification for the need to apply this nutrient even though the inefficiency of fertilizer recovery and utilization by forage grasses was significant in a subtropical, semiarid environment.

\section{Literature Cited}

Blue, W.G. 1971. Nitrogen fertilization in relation to seasonal Pensacola bahiagrass (Paspalum notatum Flugge) forage nitrogen and production on Leon fine sand. Proc. Soil Crop Sci. Fla. 31:75-77.
Bremner, J.M. 1965. Inorganic forms of nitrogen. In: C.A. Black (ed.) Methods of soil analysis. Part 2. Agronomy 9:1179-1237. Amer. Soc. Agron., Madison, Wis.

Fairbourn, M.L. 1982. Water use by forage species. Agron. J. 74:62-66.

Gonzalez, C.L., and J.H. Everitt. 1982. Nutrient contents of major food plants eaten by cattle in the South Texas Plains. J. Range Manage. 35:733-736.

Holt, E.C., and R.L. Dalrymple. 1979. Seasonal patterns of forage quality of weeping lovegrass cultivars. Agron. J. 71:59-62.

Impithuks, V., and W.G. Blue. 1985. Fertilizer nitrogen and nitrogen-15 in three warm-season grasses grown on a Florida Spodosal. Soil Sci. Soc. Amer. J. 49:1201-1204.

Jackeon, M.L. 1970. Soil chemical analysis. Sixth printing by the author. Dep. of Soil Sci. Univ. Wisconsin, Madison. p. 174-204. (First published in 1958 by Prentice-Hall, Inc., Englewood Cliffs, N.J.).

Lorenz, R.J., and G.A. Roder. 1972. Forage production and botanical composition of mixed prairie as influenced by nitrogen and phosphorus fertilization. Agron. J. 64:244-249.

Mutz, J.L., and D.L. Drawe. 1983. Clipping frequency and fertilization influence herbage yields and crude protein content of 4 grasses in South Texas. J. Range Manage. 36:582-585.

Prine, G.M., and G.W. Burton. 1956. The effect of nitrogen rate and clipping frequency upon the yield, protein content and certain morphological characteristics of coastal bermudagrass (Cynodon dactylon, $(\mathrm{L})$ Pers.). Agron. J. 48:296-301.

\section{Yield per Unit of Rainfall}
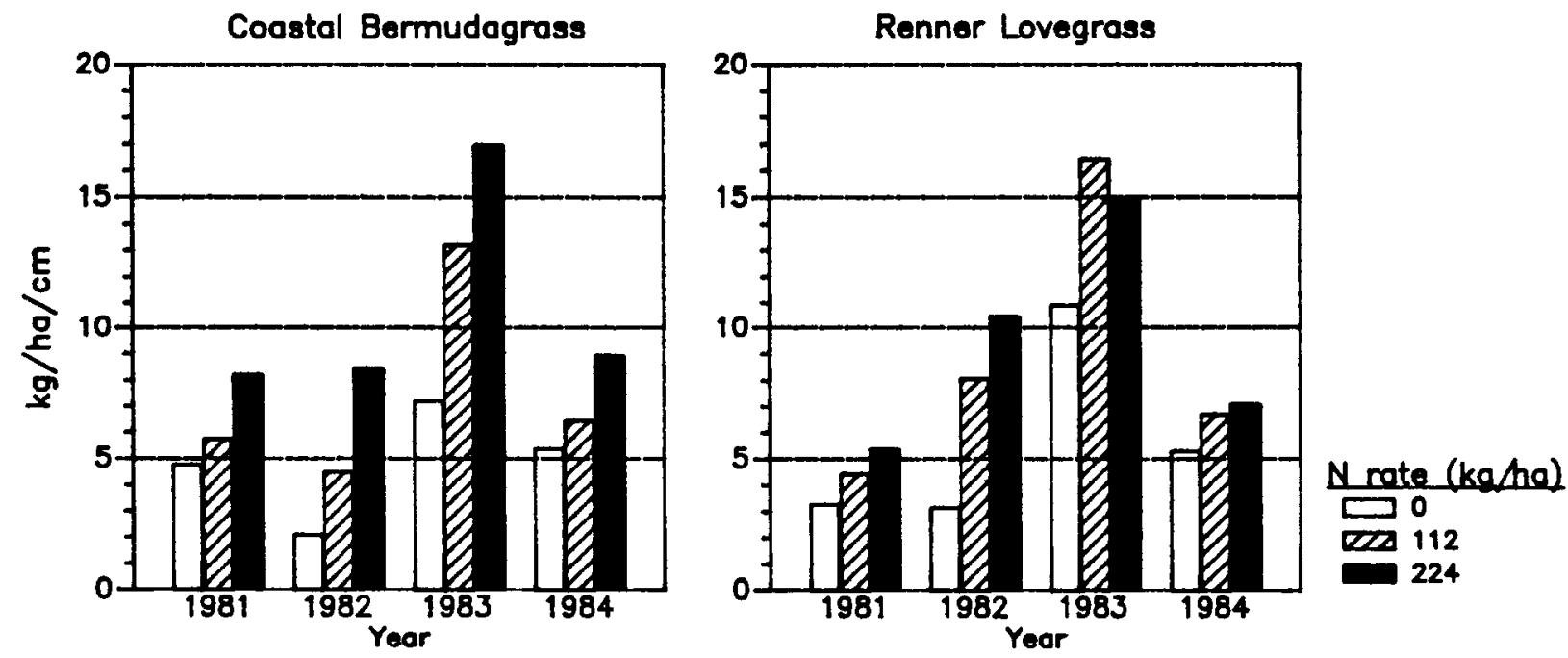

Fig. 5. Dry matter forage yields per $\mathrm{cm}$ of annual rainfall received at 3 levels of $N$ application for 4 years by 2 forage grasses. 
Ruasel, D.A., W.J. Free, and D.L. McClune. 1974. Potential for fertilizer use on tropical forages. p. 39-65. In: D.A. Mays (ed.). Forage fertilization. Amer. Soc. Agron., Crop Sci. Soc. Amer. and Soil Sci. Soc. Amer. Madison, Wis.

SAS Instlitute, Inc. 1985. SAS users guide: Statistics, Version 5 edition. SAS Institute, Inc., Cary, NC.

Thomas, J.R., and A. Osenbrus. 1964. Interrelationships of nitrogen, phosphorus, and season precipitation in the production of bromegrasscrested wheatgrass hay. USDA-ARS Production Res. Rep. No. 82 .

Wallace, A.T., G.B. Killinger, R.W. Bleduoe, and D.B. Duncan. 1955. Effect of nitrogen fertilization on the production of pangolagrass and bahiagrass. Soil Sci. Soc. Fla. Proc. 15:198-207.
Wiedenfeld, R.P., W.T.W. Woodward, and R.R. Hoverson. 1985. Forage responses of buffelgrass and 'Pretoria $90^{\circ}$ ' bluestem to nitrogen and phosphorus fertilization in a subtropical climate. J. Range Manage. 38:242-246.

Wight, J.R. 1976. Range fertilization in the Northeastern Great Plains. J. Range Manage. 29:180-185.

Wight, J.R., and A.L. Black. 1978. Soil water use and recharge in a fertilized mixed prairie plant community. J. Range Manage. 31:280-282.

Wisht, J.R., and A.L. Black. 1979. Range fertilization: plant response and water use. J. Range Manage. 32:345-349. 